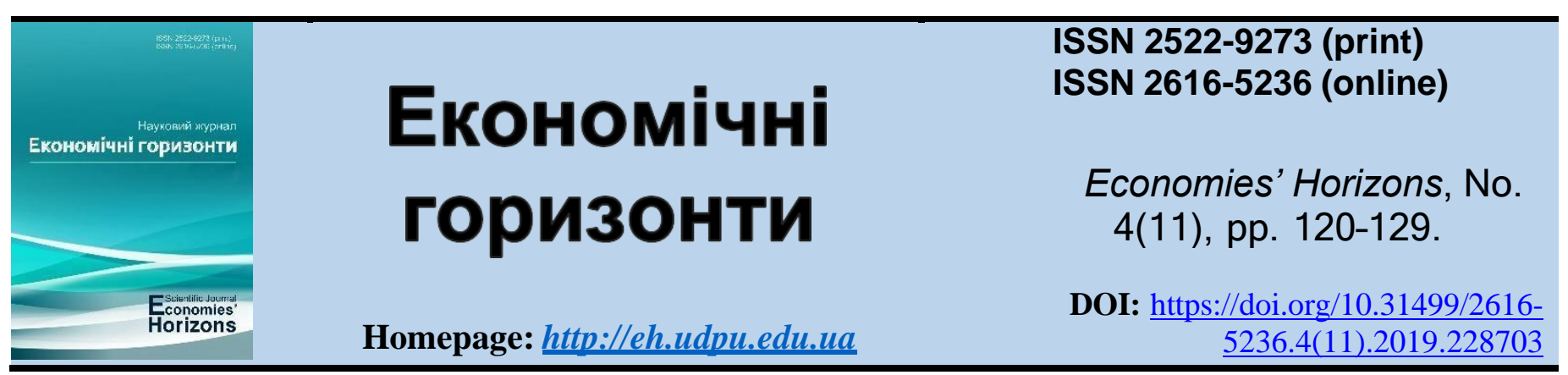

UDC 331.101.262: 334.7

JEL Classification: C 40, J31, J53, Z20, M 20, O 29.

\title{
Methodical approaches to assessing the impact of labor development indicators on the performance of enterprises
}

\section{M.I. Koval ${ }^{1}$, Candidate of Economic Sciences, Associate Professor, B.Yu. Melnyk ${ }^{2}$, Graduate Student}

Abstract. The purpose of the study is to substantiate the possibility of applying new methodological approaches to assess the impact of significant indicators (factors) of labor potential on the results of the enterprise by using methods of factor analysis and obtaining bottlenecks for practical application of relevant management issues aimed at improving the results of research enterprises. The mechanism of application of new methodical approaches to determination of influence of internal indicators (factors) of development of labor potential of the enterprise on the results of financial and economic activity of enterprises by the use of special mathematical tool - methods of the factor analysis are investigated. The choice of indicators that adequately reflect the forms of manifestation of the essence of the studied phenomenon for such a factor analysis is an extremely important problem.

Methodology. In our case, sixty-seven indicators characterizing their labor potential were selected at three enterprises. Thirty-six of the most valuable of them were selected due to the use of mathematical statistics, which served as input for factor analysis, as a result of which the authors obtained a matrix of factor loadings of indicators characterizing the labor potential of the studied enterprises. The practical significance of the study is that, as a result, the most significant factors of influence were identified for each of the studied enterprises. Taking into account these factors, it is possible to effectively manage the development of labor potential of the enterprise in the direction of improving the results of their financial and economic activities.

Key words: development of labor potential, methods of factor analysis, classification

\footnotetext{
${ }^{1}$ Private Joint-Stock Company "Higher Educational Institution" Interregional Academy of Personnel Management ": Head of the Department of Accounting and Taxation; ORCID: https://orcid.org/0000-0003-4544-6834; email:

${ }^{2}$ Private Joint-Stock Company "Higher Educational Institution" Interregional Academy of Personnel Management ": graduate student; ORCID identifier - https://orcid.org/0000-0002-8861-0107; email: bogdan.melnyk.23@gmail.com
} 
of methods of factor analysis, matrix of factor loadings of labor potential indicators, graphs of factor loadings, multiple regression equation.

Keywords: strategic development, sports industry, innovations, knowledge economy, education and science system, human capital, human potential.

\title{
Методичні підходи до оцінки впливу показників розвитку трудового потенціалу на результати діяльності підприсмств
}

\author{
М.І. Коваль ${ }^{1}$, к.е.Н., доцент, \\ Б.Ю. Мельник ${ }^{2}$, аспірант
}

Анотація. Метою дослідження є обгрунтування можливості застосування нових методичних підходів до оцінки впливу істотних показників (факторів) розвитку трудового потенціалу на результати діяльності підприємства шляхом використання методів факторного аналізу та отримання вузьких місць для практичного застосування відповідних управлінських питань, спрямованих на підвищення результатів діяльності досліджуваних підприємств (прибутку). Розкрито механізм застосування нових методичних підходів до визначення впливу внутрішніх показників (факторів) розвитку трудового потенціалу підприємства на результати фінансово-господарської діяльності підприємств шляхом використання спеціального математичного апарату - методів факторного аналізу. Для проведення такого факторного аналізу надзвичайно важливою проблемою є вибір показників, що адекватно відображають форми прояву сутності досліджуваного явища.

Методологія. У нашому випадку по трьох підприємствах були відібрані 67 показників, що характеризують трудовий потенціал зазначених підприємств. Із них, внаслідок застосування інструментарію математичної статистики та кореляційнорегресійного аналізу, було відібрано 36 найбільш цінних, які слугували вхідною інформацією для факторного аналізу, внаслідок якого авторами було отримано матрицю факторних навантажень показників, що характеризують трудовий потенціал досліджуваних підприємств. Практичне значення дослідження полягає в тому, щэо в результаті по кожному із досліджуваних підприємств були визначені найбільш істотні фактори впливу, враховуючи які можна здійснювати ефективне управління розвитком трудового потенціалу підприємств у напрямі підвищення результатів їх фінансовогосподарської діяльності.

Ключові слова: розвиток трудового потенціалу, методи факторного аналізу, класифікація методів факторного аналізу, матриця факторних навантажень показників трудового потенціалу, графи факторних навантажень, рівняння багатофакторної регресії.

\footnotetext{
${ }^{1}$ Приватне акиіонерне товариство «Вищий навчальний заклад «Міжрегіональна Академія управління персоналом»: завідувач кафедри обліку і оподаткування; ідентифікатор ORCID : https://orcid.org/0000-0003-4544-6834; електронна adpeca: karolinadavydenko618@gmail.com

2 Приватне акиіонерне товариство «Вищий навчальний заклад «Міжрегіональна Академія управління персоналом»: аспірант; ідентифікатор ORCID - https://orcid.org/0000-0002-8861-0107; електронна адреса: bogdan.melnyk.23@gmail.com
} 
1. Introduction. Modern trends in the development of the Ukrainian economy cause the need to in a new way to perceive a set of resources that uses an enterprise in its activities, including human. Personnel management in conditions of development of sociooriented society requires consideration, along with the ability of employees to work, also their socio-psychological qualities, intellectual level, opportunities for their innovation, transformation of business processes in the direction of digitalization, the activation of which allows you to more fully realize. Labor potential of the enterprise.

Formulation of the problem. In the current market conditions of management, the proper development of labor potential, as a decisive precondition for socio-economic stabilization, becomes the basis for ensuring the productivity of the national economy. At the same time, there are a complication of reproductive factors in the state of labor potential, there are negative trends in the structure of employment and labor quality. In addition, it should be objectively noted that enterprises almost lost control over the state of its labor potential and processes of its formation and use. Thus, the financial crisis, bankruptcy and closure of a significant number of enterprises, low wage levels determine the general deterioration of the professional qualification level of employees, their moral, motivational and creative potentials, which, in turn, prevents the necessary restructuring and introduction of the latest technologies, and Also, an increase in the release of competitive products by enterprises of Ukraine.

All this requires urgent measures in the field of development of labor potential of enterprises aimed at increasing the results of their activities, which ultimately will promote the improvement, stabilization and development of enterprises of the leading branches of the country's economy.

2. Literature review. Currently, a significant number of domestic and foreign scholars and practitioners in the field of development of labor potential of enterprises highlight certain transformational processes that are currently taking place in the appropriate environment, their problems. Among them E. Vagney and M. Podkidchenko (Vahyna and Podkydchenko, 1990), M. Dziamulich (Dziamulych, 2002), O. Drebot (Drebot, 1999), A. Yegorshin (Ehorshyn, 2001), V. Zwass (ZWASS, 1996), C. Winfield Treese, S. Stewart Lawrence (Treese, Stewart Lawrence, 1998), Ö. Livarçin and D. Kurt (Livarçin and Kurt, 2012), A. Yegorshin and L. Palacter (Yehorshyn and Maliarets, 1999), V. Smolyuk (Smolyuk, 2008) and others.

3. Methods. To detect the influence of internal factors of development of labor potential for the results of financial and economic activity of three investigated enterprises, a special mathematical apparatus was used - methods of factor analysis and tools of mathematical statistics, in particular methods of regression analysis. Based on the received matrix of factor loads, in each of the investigated enterprises, the most significant factors of influence were obtained, which allow to predict the results of enterprises. Using the equation of multifactor regression, the authors built the corresponding regression model whose quality was carried out with the help of statistical criteria $\mathrm{T}$ - Student estimates, the 
F-criterion for the adequacy of the model and multiple coefficients of the correction and determination. The results of the analysis allowed the authors to build relevant graphs of the most significant factor loads for each enterprise and a graph of confirmation of the adequacy of the model obtained.

4. Research objectives. The main purpose of the study to assess the impact of significant factors in the development of labor potential on financial and economic results of enterprises through the use of factor analysis methods and special tools of mathematical statistics, which allows to identify the relevant "bottlenecks", which can be applied to the relevant management decisions aimed at increasing the results the activities of investigated enterprises.

\section{Results and discussions.}

In the process of analyzing the quantitative and qualitative part of the development of labor potential and the construction of a general integral indicator of its assessment, certain conclusions regarding its level of development can be made. But it should be noted that conducting analysis by the method of coefficients is complicated due to the absence of forms of taking into account relationships between individual coefficients, their relative autonomy, differences in the levels of critical values, non-manifestations, multidirectional trends. In addition, the same coefficients may be the effects of various reasons that complicates the acquisition of objective conclusions.

In order to determine and specify measures in the process of managing the development of labor potential of a particular enterprise, in our opinion, it is necessary to identify the most significant factors that directly affect the results of its activities. The direction of managers to the most significant factors, modification of their values, depending on a particular situation, will increase the efficiency of labor potential management as a whole. In order to determine the most significant factors, it is advisable to use methods of factor analysis, in particular the method of regression analysis for the study of sources of influence on the effectiveness of the enterprise. These factors are determined by the existence of relatively established causal relationships, for example, in the processes of functioning and development of a business entity (Livarçin and Kurt, 2012). Such relatively established links were called "internal hidden factors of influence on the process of functioning and development of the socio-economic system", which in our case is an enterprise.

Considering the set of enterprises as a holistic socio-economic system, which inherent in the internal features, with the help of a factor analysis, can determine the regular typical combinations of values of directly measured features that are most commonly found.

Obtained as a result of analysis Internal factors have a property to significantly reduce information, maintaining its value. In practice, the indicators describing the labor potential of the enterprise are too aborted. This negative phenomenon complicates the entire analysis process that is based on linear regression models. Factor analysis helps to find those variables, between which there is no correlation or it is too small to consider it as a problem. Due to the uncorrelated factors, a statistical analysis of regression equations is simplified (it is possible to avoid computational complexities for solving normal equations). Consequently, for the study of sources of influence on the effectiveness of the enterprise it is expedient to use regression analysis, whose entrance data is received by latent factors.

In the formation of initial information for a factor analysis, an extremely important problem is the choice of indicators that 
adequately reflect the forms of the essence of the phenomenon under study. The system of indicators must integrate into the company's labor potential, so the analysis of the initial information should consist of several stages. In the first stage, a meaningful analysis is carried out, which is a theoretical justification of signs of phenomenon, its conceptualization, a list of qualitative characteristics, which in general, and in particular, according to components, describe the multidimensional forms of its manifestation (Treese, Winfield., Stewart Lawrence, 1998).

The result of the first stage of analysis is a content, a qualitatively substantiated system of indicators of labor potential of the enterprise, which characterize its quantitative

$$
v_{i}=\frac{\sigma_{i}}{\bar{x}_{i}}
$$

The indicator of the relative information value of the feature is determined by the formula:

$$
\varpi_{i}=\frac{v_{i}}{\sum_{i=1}^{n} v_{i}},
$$

where $n-$ the number of indicators of signs selected by meaningful analysis..

Value $\varpi_{i}$ has to meet the conditions: $\varpi_{i} \geq 0, \sum_{i=1}^{n} \varpi_{i}=1$

Based on the calculated indicators of absolute and relative information value, we are able to reject those signs that do not have values for cognition (in terms of economic and mathematical modeling). These are, as a rule, those indicators whose values are steady or almost sustainable. In addition, specify a defined threshold value $\varepsilon$ and by its help, the indicators are discarded, which are changing. For such signs, the ratio is performed: $v_{i} \leq \varepsilon$ чи $\varpi_{i} \leq \varepsilon$, де $\varepsilon$-was rather an inalienable value (for example - 0.1).

Consequently, to solve such tasks and qualitative parties. The second stage is realized by means of tools for mathematical statistics. Initially, the system of indicators must be protested to "clogging". Selected indicators should have an information value. Modern scientists-researchers of these phenomena (Vahyna, Podkydchenko, 1990; Drebot, 1999; ZWASS, 1996) recommend to calculate the absolute and relative information value of indicators that characterize the signs of phenomena. According to their recommendations, the indicator of the absolute information value of qualities is the coefficient of variation calculated according to the known formula (the average quadratic deviation of the indicator refers to its average value): it is advisable to use a statistical package - Statistica 6.

As you can see, the first, and therefore, the most substantial factor is formed by indicators $\mathrm{x}_{16}, \mathrm{x}_{29}, \mathrm{x}_{5}, \mathrm{x}_{8}, \mathrm{x}_{36}$, $\mathrm{x}_{35}, \mathrm{x}_{34}, \mathrm{x}_{33}, \mathrm{x}_{14}, \mathrm{x}_{15}, \mathrm{x}_{24}, \mathrm{x}_{22}$. This sequence is formed by reducing indicators of factor loads, namely: X16 (0,757) - all-day simple ones per employee; X5 (0.745) - off workers by reducing states; X8 $(0,703)$ - turnover ratio; X30 $(0,551)$ - labor arrangement; X36 $(-0,936)$ - the state of the innovative potential of employees; X35 (-0,921) the state of intellectual potential of 
employees; X34 (0.885) - the state of the socio-psychological potential of employees; X33 $(-0,848)$ - the state of cultural and moral potential of employees; X14 (-0,836) - average number of hours of work of one employee; X24 (-0,711) - Table Fund of Work of One Worker; X22 (-0,701) Max. possible fund of the work of the 1st employee; X27 (-0,700) - productivity.

We will construct the graph of the most important factor loads that characterize the use of working time and the state of the qualitative component of the labor potential of the enterprise (Fig. 2).

As you can see from Fig. 2, the most significant factors of loads that characterize the use of working time and the state of the qualitative component of labor potential that respond to the efficiency of the enterprise (the conditional name of the enterprise - F1) is: the turnover ratio of retirement, extinguished by reducing the states and the work of labor. These weight factors allow the enterprise to schedule further development of its economic component. The presented indicators and their sequence suggest that this factor characterizes the time worked by the workers of the enterprise, as well as the level of development of qualification, cultural, socio-psychological, intellectual and innovative employees' potentials.

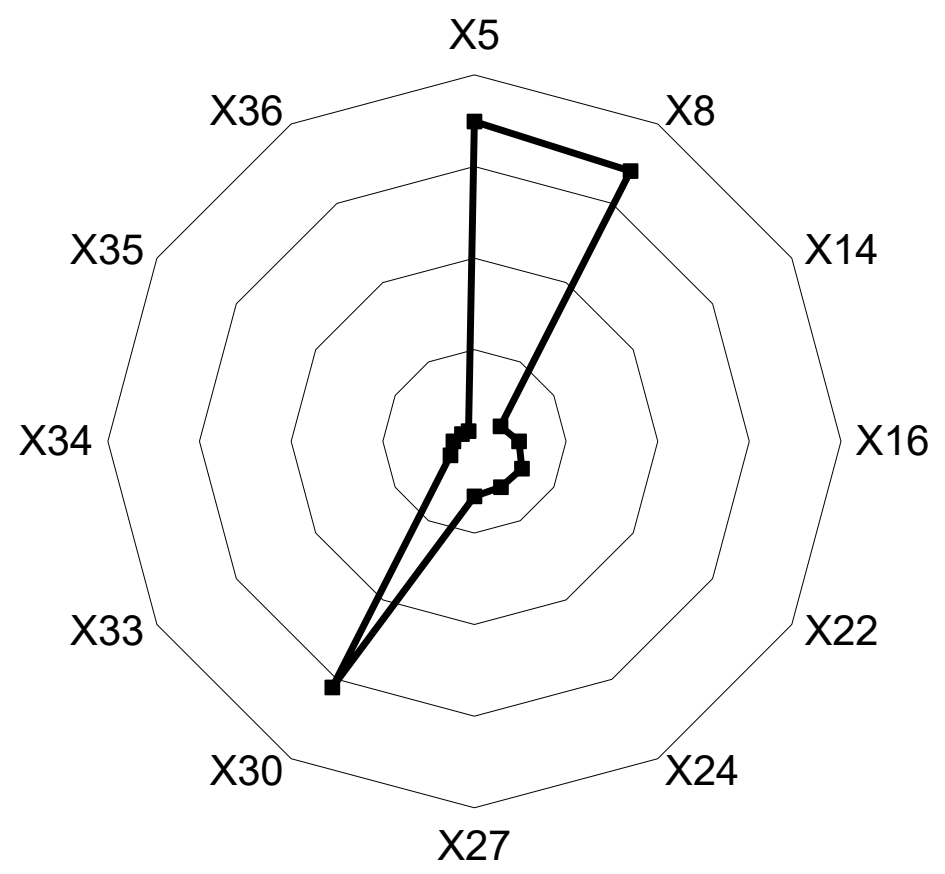

Fig. 2. The graph of the most significant factor loads characterizing the use of working time and the state of the qualitative component of the labor potential of the enterprise

Source: Built by authors

The second factor is formed by indicators: X1 (0.945) - the number of full-time employees; X2 (0.940) accounting number of employees; X11 $(0,919)$ - the number of employees with higher education; X4 $(0,823)$ - off workers at their own desire, for absenteeism and violation of labor discipline; X3 (0.779) - the number of retired workers; X17 (0.744) - non- 
employment of one employee; X6 (0.731) - accepted to work; X13 (0.709) - increased qualifications; X32 (-0,464) the state of the qualification potential of employees. The corresponding graph is shown in Fig. 3.

As you can see from Fig. 3, the most significant factors of loads that characterize changes in the number and their qualification levels, which provide effective increase in the economic development of the enterprise: the number of full-time employees, the accounting number of employees, the number of employees who delayed: employees who have been delayed by their own desires and for violation. Labor discipline, employees accepted, advanced training and failures to work per employee. These factors make it possible to evaluate the internal potential of the enterprise and to predict the procedure for action for further effective functioning.

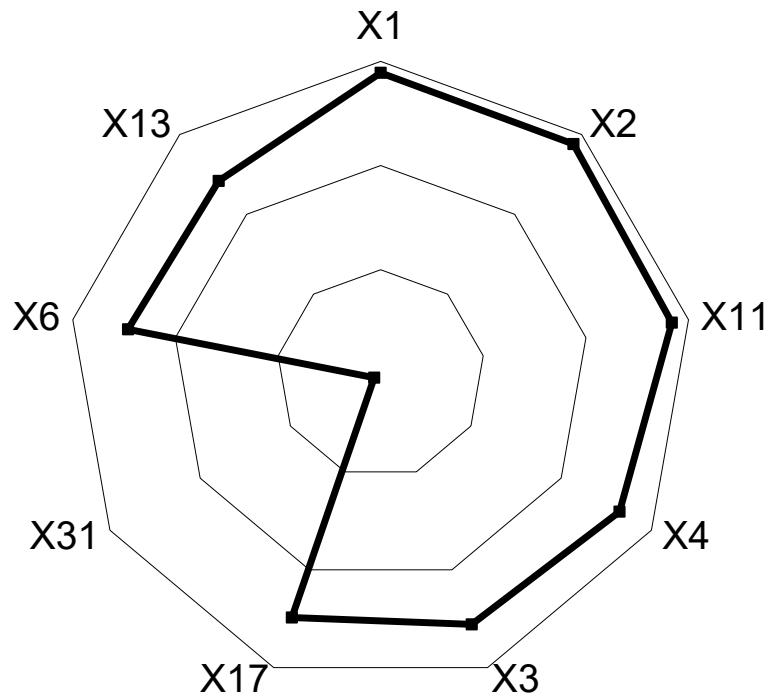

Fig. 3. Count of the most significant factor loads characterizing changes in the number of employees and in their qualification level of the enterprise

Source: Built by authors

Such a sequence of indicators characterizes the level of adequacy of the number of employees of the enterprise, its changes, as well as the level of education and professional training, production experience, qualifications, labor skills, labor activity and mobility.

The third factor includes indicators: X10 (0.745) - coefficient of general turnover, X21 $(-0,758)$ - the number of absent of absence per employee and X18 (-0,709) - educational leave. This factor characterizes the intensity of movement of frames at the enterprise. The corresponding graph is shown in Fig. 4.

Thus, according to the results of factor analysis, we received the opportunity to evaluate the labor potential of the enterprise not in 36 indicators, and according to the new three generalized characteristics received significant factors that significantly reduce the information 
space, preserving the basic requirement of information - its value.

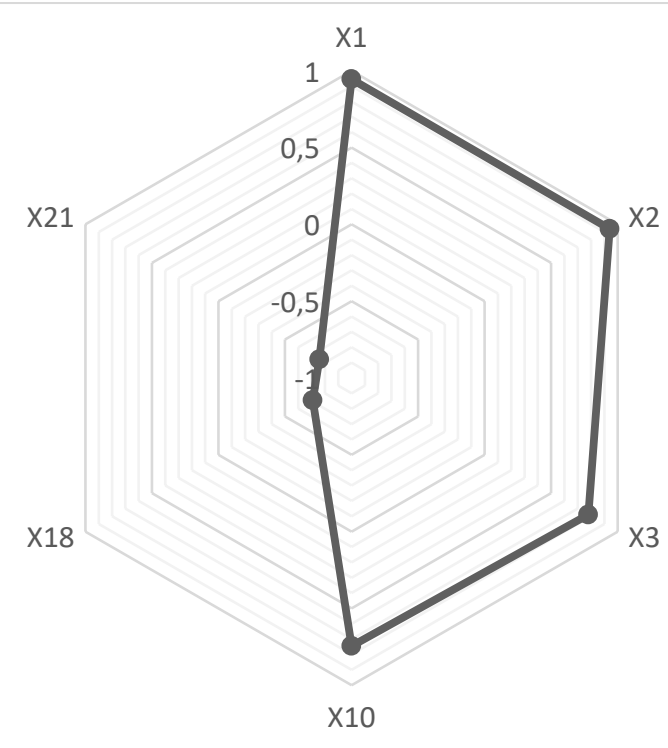

Fig. 4. The graph of the most significant factor loads characterized by the coefficient of general traffic and the intensity of the movement of personnel at the enterprise

Source: Built by authors

The method of factor analysis also provides for the use of the results obtained to predict the results of the enterprise based on the equation of multifactorial regression, built on detected

$\boldsymbol{y}=\sum_{i=1}^{k} b_{i} P_{i}+b_{0}$

де $y_{i}$ - результуючий показник; $P_{i}-i$-тий фактор;

$b_{i}-$ навантаження $i$-тої змінної на $i$-тий фактор;

$b_{0}$ - вільний член;

$k$ - кількість факторів.

As a resultant indicator, we have chosen a net profit per employee (U), which characterizes the relative efficiency of the enterprise.

Then built a regression model (Yehorshyn, Maliarets, 1999) will have the following form:

$0,224 \mathrm{~F} 3 ;(4)$

$$
\mathrm{Y}=-1,0786+0,874 \mathrm{~F} 1+0,057 \mathrm{~F} 2-
$$

$\mathrm{R} 2=0.817$.
Conclusions on the quality of the indicated regression equation $\mathrm{We}$ are substantiated with the help of statistical criteria - Student's estimates - the criterion of adequacy of the model, and multiple correlation and determination coefficients (evidence of the results of the computing procedures of the Factor Analysis and Multiple Regression. Statistical criteria confirm that the constructed models of regression analysis for identified factors are adequate and have a significant explanatory ability.

Relevalize the information part of the built regression model.

Y-dependent variable - the resulting indicator of net profit is selected per employee;

The number of cases that regression is built - 21 .

In the informational part, primarily pay attention to the value of the determination coefficient (R2). In this case, it is equal to 0.817. That is, the built regression explains $81.7 \%$ variation of the values of variable net 
profit per one employee relative to the average. Therefore, this model can be considered sufficiently high-quality.

Next, attention should be paid to the value of the F-criterion and level of significance P. F-criterion used to check the hypothesis on the significance of regression. The value of the F-criterion 25.26 is quite high, and the level $\mathrm{P}=0.000015$ also indicates that the constructed regression is quite significant.

In the second part of the information window, the system itself announces significant regression coefficients. Note that $\mathrm{B} 0$ is a coefficient with independent variables and significant coefficients of the first, second and third factors.

An important element of analysis is the general assessment of the adequacy of the model. Once the model adequacy is proved, the results can be confidently used for further action. The analysis of the adequacy of the model is based on the analysis of residues. The residues are the difference between the values observed and modal, that is, the values calculated by the model with the estimated parameters.

Thus, using the OBSERVED VS module. Residuals, we will receive a graph that will indicate the adequacy of the model (Fig. 5) (Yehorshyn, Maliarets, 1999).

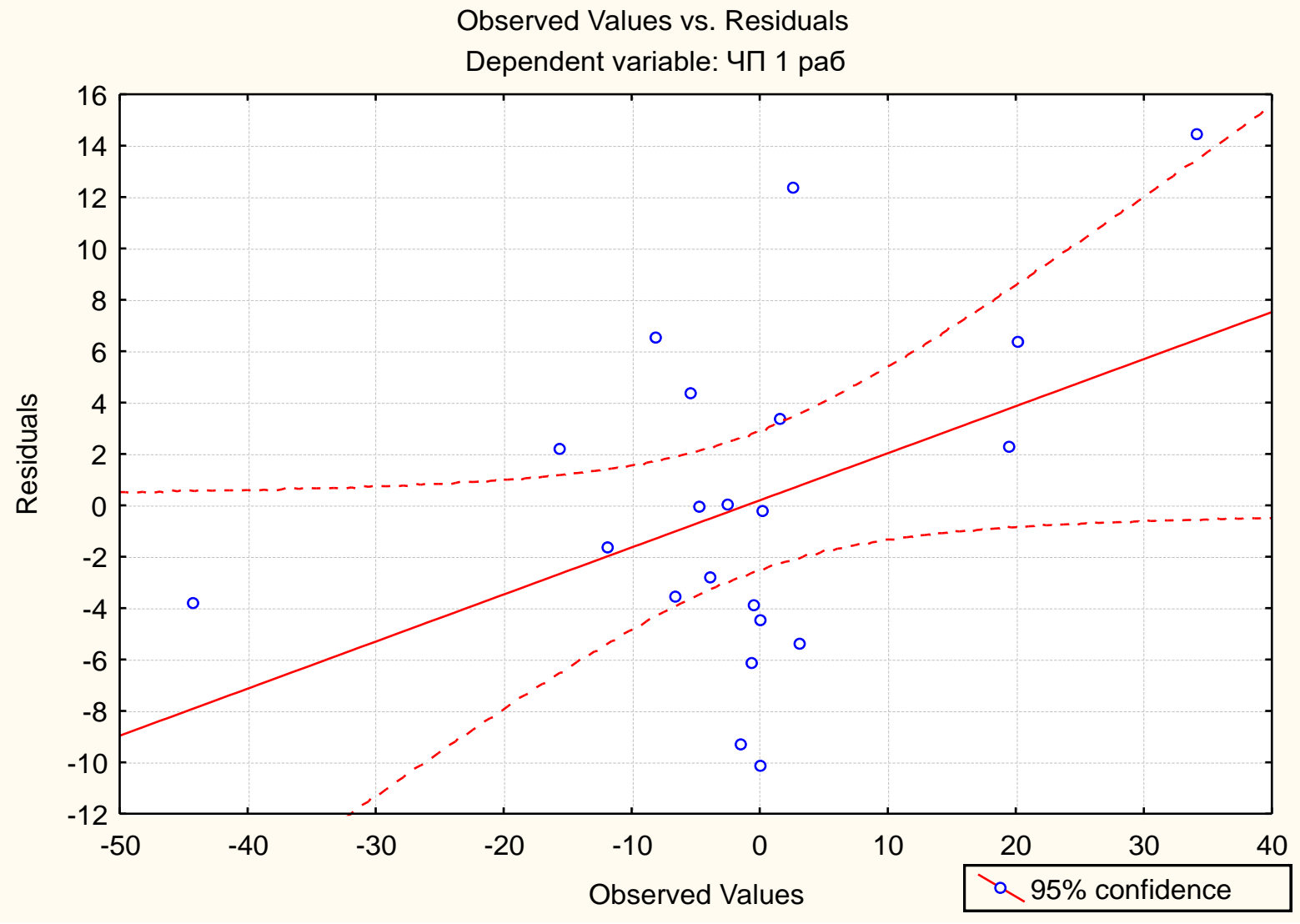

Fig. 5. Schedule confirmation of model adequacy

The above regression analysis showed that the effectiveness of the enterprise affects the following factors (their sequence is given in priority) as the use of working time and the state of the qualitative component of labor potential $\left(F_{1}\right)$,The intensity of the movement of frames at the enterprise $\left(F_{3}\right)$ and changes in the number of employees, their physical condition and educational level $\left(F_{2}\right)$.

Therefore, the above indicates the priority of implementing measures aimed at ensuring the development of a qualitative component of the labor potential of the 
enterprise and managing the proper use of working time.

\section{Conclusions.}

Consequently, the conducted research gives grounds to assert that for the definition of measures that actually affect the efficiency of labor potential of the enterprise, it is necessary to identify significant factors of influencing it by trial testing for "clogging", and their aggregate and modification, depending on the particular situation, indicating among them Adequate models due to changes in factors and their influence on the resulting index.

\section{References}

Vahyna, E.Yu., Podkydchenko, M.H. (1990). Hozyaystvennyiy mehanizm: problemyi proshlogo i nastoyaschego [Economic mechanism: problems of the past and present]. Moskow: Znanie, $64 \mathrm{p}$.

Dziamulych, M.I. (2002). Mekhanizm vidtvorennia robochoi syly v aspekti rynkovykh transformatsii [The mechanism of labor reproduction in the aspect of market transformations]. Zbirnyk naukovykh prats DNU «Ekonomika: problemy teorii ta praktyky» DNU, (125), 73-84.

Drebot, O.I. (1999). Pytannia demohrafichnoi polityky $\mathrm{v}$ umovakh sotsialnoekonomichnykh transformatsii [Issues of demographic policy in the context of socio-economic transformations]. Sotsialno-ekonomichni doslidzhennia $v$ perekhidnyi period. Osnovy formuvannia rehionalnoi sotsialno-ekonomichnoi polityky, (8), 317-327.

Ehorshyn, A.P. (2001). Upravlenie personalom: uchebnik dlya vuzov [Personnel management: textbook for universities] (3 edition). Nizhniy Novgorod: NIMB. $720 \mathrm{p}$.

Zwass, V. (1996). Electronic Commerce: Structures and Issues. International Journal of Electronic Commerce, (V.1, №1, Fall), 3-23.

Treese, C. Winfield., Stewart Lawrence, C. (1998), Designing Systems for Internet Commerce. Addison Wesley, $375 \mathrm{p}$.

Livarçin, O. and Kurt, D. (2012). «49 People 49 theory in management science [In Turkish: Yönetim biliminde 49 insan 49 Teori],», Beta Yayınları, İstanbul.

Yehorshyn, A.A. Maliarets, L.M. (1999). Koreliatsiino-rehresiinyi analiz: kurs lektsii ta laboratornykh robit [Correlation-regression analysis: course of lectures and laboratory works]. Kharkiv: Osnova, 208 p. 